\title{
Novel Diagnosis for Citrus Stubborn Disease by Detection of a Spiroplasma citri-Secreted Protein
}

\author{
Jinxia Shi, Deborah Pagliaccia, Robyn Morgan, Yongli Qiao, Songqin Pan, Georgios Vidalakis, and Wenbo Ma
}

First, second, third, fourth, sixth, and seventh authors: Department of Plant Pathology and Microbiology, and fourth, fifth, and seventh authors: Center for Plant Cell Biology, University of California, Riverside 92521.

Accepted for publication 1 August 2013

\section{ABSTRACT}

Shi, J., Pagliaccia, D., Morgan, R., Qiao, Y., Pan, S., Vidalakis, G., and Ma, W. 2014. Novel diagnosis for citrus stubborn disease by detection of a Spiroplasma citri-secreted protein. Phytopathology 104:188-195.

Citrus stubborn disease (CSD), first identified in California, is a widespread bacterial disease found in most arid citrus-producing regions in the United States and the Mediterranean Region. The disease is caused by Spiroplasma citri, an insect-transmitted and phloem-colonizing bacterium. CSD causes significant tree damage resulting in loss of fruit production and quality. Detection of CSD is challenging due to low and fluctuating titer and sporadic distribution of the pathogen in infected trees. In this study, we report the development of a novel diagnostic method for CSD using an S. citri-secreted protein as the detection marker. Microbial pathogens secrete a variety of proteins during infection that can poten-

Citrus stubborn disease (CSD) is a prevalent disease of citrus grown in arid or semiarid climates. Since its first report in 1915 in California, CSD has been found in most citrus-producing areas, including California, Arizona, North Africa, the Mediterranean Basin, and the Middle East (5,7,30). Although comprehensive studies on the impact of CSD on commercial production of citrus is limited, it is generally accepted that the damage depends on the severity of infection $(42,54)$. Reduction in orange cumulative yield due to CSD has been reported at 19 to $100 \%$, with reduction in fruit weight and size at 6 to 30 and 12\%, respectively. In addition, entire groves have been destroyed as a CSD management strategy in central California; therefore, economic damages due to CSD can be substantial $(12,34,42,55)$.

Symptoms of CSD can vary with season, citrus cultivar, and disease severity. In general, CSD-affected trees are stunted and often flattened across the top. Stems have shortened internodes with smaller leaves that are usually mottled. Most fruit drop while very small. The few fruit that could reach maturity are misshapen and abnormally matured with aborted seed $(7,10,54)$. These disease symptoms can be easily confused with those associated with nutritional deficiencies or other bacterial diseases such as huanglongbing (HLB) (also known as citrus greening) $(7,8,11$, $13,45)$. Therefore, it is important to develop robust disease detection for CSD.

The CSD causative agent Spiroplasma citri belongs to a group of cell-wall-less bacteria that are collectively called mollicutes.

Corresponding author: W. Ma; E-mail address: wenboma@ucr.edu

* The $e$-Xtra logo stands for "electronic extra" and indicates that Figures 1 and 3 appear in color online.

http://dx.doi.org/10.1094/PHYTO-06-13-0176-R

(C) 2014 The American Phytopathological Society tially disperse systemically in infected plants with the vascular flow. Therefore, their distribution may not be restricted to the pathogen infection sites and could be used as a biological marker for infection. Using mass spectrometry analysis, we identified a unique secreted protein from $S$. citri that is highly expressed in the presence of citrus phloem extract. ScCCPP1, an antibody generated against this protein, was able to distinguish S. citriinfected citrus and periwinkle from healthy plants. In addition, the antiserum could be used to detect CSD using a simple direct tissue print assay without the need for sample processing or specialized lab equipment and may be suitable for field surveys. This study provides proof of a novel concept of using pathogen-secreted protein as a marker for diagnosis of a citrus bacterial disease and can probably be applied to other plant diseases.

Additional keywords: bacterial pathogens, effectors.
Mollicutes, including phytoplasmas and spiroplasmas, are pathogens that cause many important diseases in plants and animals (28). In addition to $S$. citri, S. kunkuii is a major pathogen of maize and $S$. phoeniceum is responsible for periwinkle yellows. $S$. citri is injected into the phloem sieve tubes by phloem-feeding leafhoppers that are infected by the bacterium (33). The main economic hosts of $S$. citri include the major commercial citrus species, including grapefruit, lemon, mandarin, orange, and sour orange (21). S. citri has also been detected from carrot in Washington (37) and California (43), with symptoms of general stunting, rosette formation, and yellow-purple discoloration on leaf margins (37); and isolated from horseradish with brittle root disease with symptoms of foliar chlorosis, stunting, and discoloration in the phloem ring of affected roots (24). This incidence reflects the adaptation of $S$. citri to new hosts.

Although CSD has been a research subject for decades, robust diagnosis of the disease remains challenging. In recent years, polymerase chain reaction (PCR)-based detections have been developed using primers amplifying the highly abundant spiralin gene $(25,47)$ or multicopy genes encoding membrane proteins (56). However, PCR-based methods, which require the presence of pathogen cells or DNA in the plant sample tested, may result in erratic detection because $S$. citri has highly uneven distribution in infected trees, especially when titer is low $(7,30,55)$. Other more definitive diagnostic methods include bioindexing and culturing in artificial media, both of which are time consuming and labor intensive (7). Although sensitivity of $S$. citri to antibiotics in vitro and remission of disease symptoms in planta have been demonstrated similar to other phloem-colonizing and insect-transmitted bacterial pathogens, there is no practical cure for CSD once a tree becomes infected. Therefore, the control of the disease is heavily dependent on preventative and roughing measures which, in turn, are based on accurate and early detection $(4,6,9,19,32,38,54)$. As such, new diagnostic methods that can robustly detect CSD are 
urgently needed for field surveys and quarantine practices to ensure clean source trees for the industry.

Serological detections using antibodies targeting pathogenspecific proteins support economical and accurate diagnosis. Several antibodies were generated using $S$. citri cell cultures as the antigens $(18,23,49)$; however, a detection kit developed using some of these antibodies failed to detect some California isolates that are commonly used as positive controls (47), suggesting that these antibodies are not suitable for accurate diagnosis. Here, we set out to identify pathogen proteins that can be used as markers for such serological detection. We are particularly interested in proteins that are secreted from $S$. citri into the phloem because these secreted proteins could be dispersed throughout the infected trees along with the vascular flow and, thereby, are not restricted to the infection sites. As such, they could be used as promising detection markers by overcoming uneven distribution of the pathogen cells in infected trees.

Many bacterial pathogens rely on the secreted proteins (effectors) to cause disease on plant and animal hosts (22). Some effectors are injected directly into host cells through specialized protein secretion apparatus, such as the type II and III secretion systems (1). These specialized protein delivery systems are not present in $S$. citri (48). This is not surprising because, as an intracellular pathogen injected into phloem by insect vectors, $S$. citri proteins secreted through the general Sec secretion system are readily located inside the plant tissues. Similarly, specialized protein delivery systems are also absent in other intracellular pathogens, including 'Candidatus Liberibacter', the bacterium associated with HLB $(20,40)$.

Systemic movement of the secreted proteins by insect-transmitted and phloem-colonizing bacteria has been reported in phytoplasmas, the closest relatives of spiroplasmas. The aster yellows phytoplasma secretes 56 proteins through the Sec secretion system into the phloem (3). Two of these effectors significantly contribute to plant defense suppression and disease symptom development (41,53). Remarkably, although phytoplasma cells are restricted to the phloem sieves, these effectors can systemically move along the phloem and be transported to shoot and root meristem. Moreover, some phytoplasma effectors can also be uploaded from phloem to the neighboring tissues and manipulate physiological processes in these plant cells $(31,41)$. Thus, effectors produced by phloem-colonizing bacterial pathogens can have profound impacts on plant development and systemic resistance.

In order to explore the concept of using secreted proteins of bacterial pathogens as detection markers for diagnosis, we identified a unique Sec-secreted protein of $S$. citri by mass spectrometry. An antibody, called ScCCPP1, was generated against this secreted protein and used to detect specific signals from $S$. citri-infected citrus trees using a simple direct tissue print assay. The signals were mainly from the phloem-rich tissues, consistent with the primary location of the pathogen (26). Importantly, ScCCPP1-based detection gave comparable, and in some cases, more reliable and consistent results than the PCR-based assays and was also superior to an antibody generated against the spiralin protein, a major $S$. citri cell membrane component. These data demonstrate that ScCCPP1 antibody can detect CSD in the absence of $S$. citri cells and, therefore, is an excellent marker for disease diagnosis.

\section{MATERIALS AND METHODS}

Plant materials. Sweet orange (Citrus sinensis L. Osb.) and pummelo ( $C$. maxima Burm.) that were graft inoculated with $S$. citri strains C189, S600, and S616 were used as S. citri source plants and maintained at the Rubidoux quarantine greenhouse of the Citrus Clonal Protection Program (CCPP) at the University of California (UC) Riverside (32 to $38^{\circ} \mathrm{C}$ during the day and $>27^{\circ} \mathrm{C}$ at night). Inoculum from these $S$. citri source plants was used to graft inoculate sweet orange seedlings that were subsequently used in the present study. Inoculated and healthy sweet orange plants were then maintained under standard greenhouse conditions at the UC Riverside Agricultural Operations greenhouse at temperatures of 18 to $35^{\circ} \mathrm{C}$.

Periwinkle (Catharanthus roseus) 'Jaio Dark Red' plants were propagated by seed and mechanically inoculated with $S$. citri strain C189 axenic culture on the stems of 3-month-old seedlings using a biojector gun (http://www.bioject.com/) as described below. Both the inoculated periwinkle plants and the noninoculated controls were maintained at the UC Riverside Agricultural Operations greenhouse.

Finally, plant materials from naturally infected sweet orange trees planted in 1983 in field 12B of the UC Riverside Agricultural Operations were also used in this study in October 2012 and April 2013.

Bacterial cultivation. $S$. citri stain $\mathrm{C} 189$ was isolated from a CSD-symptomatic citrus tree of the CCPP disease bank. Phloemrich tissues (leaf midveins and petioles) were excised, surface sterilized, and diced with a sterile razor blade before being suspended in $10 \mathrm{ml}$ of LD8 broth medium (36). The suspension was passed through a $0.45-\mu \mathrm{m}$ filter, then incubated at $30^{\circ} \mathrm{C}$. Presence of $S$. citri was confirmed after 3 and up to 14 days by examining 10 to $20 \mu$ lof the culture under a dark-field microscope $(\times 1,000)$ (Leica DMLB) for the presence of motile, helical spiroplasma cells.

Periwinkle inoculation. We used a biojector 2000 injection system gun to inoculate periwinkle plants with $S$. citri strain C189. Each plant was injected three times with $200 \mu$ of bacterial inoculum with the concentration of $S$. citri at $\approx 10^{9} \mathrm{CFU} / \mathrm{ml}$. To prepare the inoculum, $S$. citri cells were collected from $240 \mathrm{ml}$ of 3-day-old culture grown in LD8 medium by centrifugation at $9,000 \times g$ for $30 \mathrm{~min}$. The precipitated cell pellet was resuspended in $15 \mathrm{ml}$ of fresh LD8 medium, which was then loaded in a biojector for inoculation. Plants inoculated with clean LD8 medium (mock infected) were used as negative controls. DNA and proteins were extracted from newly emerged tissues away from the inoculation sites at 0 and 8 days postinoculation (dpi), and thereafter at 14-day intervals for a total of 110 days.

Secreted protein extraction. Proteins secreted from the $S$. citri cells in liquid culture in the presence of citrus phloem extracts were analyzed using mass spectrometry. Phloem extracts were made by cutting off a long branch from a healthy sweet orange seedling. Five grams of the phloem-rich outer layer (i.e., bark) was separated from the branch and ground in a mortar and pestle in liquid nitrogen. The tissue powder was suspended into $3 \mathrm{ml}$ of distilled water and incubated on ice for $1 \mathrm{~h}$. The supernatant of the phloem extract was then filter sterilized and stored in $-80^{\circ} \mathrm{C}$. $S$. citri cells were collected from $3 \mathrm{ml}$ of 1-week-old culture grown in C-3G medium (39) and suspended in $500 \mu \mathrm{l}$ of $0.3 \mathrm{M}$ sucrose supplemented with $250 \mu \mathrm{l}$ of the phloem extract at $30^{\circ} \mathrm{C}$ without shaking for $24 \mathrm{~h}$. Secreted proteins induced in the presence of citrus phloem extracts were identified by comparing the relative abundance in the induced versus noninduced samples. Three independent biological replicates were analyzed.

Supernatant of the induced cell culture was collected by centrifugation at $10,000 \mathrm{rpm}$ for $5 \mathrm{~min}$. The cells were further eliminated from the supernatant portion by repeating the centrifugation. Proteins in the cell-free supernatant were precipitated by ice-cold trichloroacetic acid (TCA)-acetone (50) using a modified protocol. Briefly, the supernatant was mixed with nine volumes of acetone containing $10 \%$ TCA and $20 \mathrm{mM}$ dithiothreitol (DTT) at $-20^{\circ} \mathrm{C}$ overnight. Proteins were precipitated by centrifugation at $6,800 \times g$ for $5 \mathrm{~min}$ at $4^{\circ} \mathrm{C}$. The pellet was washed twice with icecold acetone containing $20 \mathrm{mM}$ DTT, air dried for $5 \mathrm{~min}$, then dissolved in $50 \mathrm{mM} \mathrm{NH}_{4} \mathrm{HCO}_{3}$ solution.

Proteomic analysis. Sodium dodecyl sulfate polyacrylamide gel electrophoresis (SDS-PAGE) gel slices containing candidatesecreted proteins from the phloem extract-induced $S$. citri cells 
were analyzed by mass spectrometry for protein identities. Relative abundance of individual proteins was estimated based on the number of peptides from each protein that were detected. The identities of the secreted proteins were determined using a Bruker UltraReflex III MALDI-TOF/TOF mass spectrometer (Bruker Daltonics, Karlsruhe, Germany) operated in reflection mode. The proteins were digested with porcine trypsin, then solubilized in $2 \mu \mathrm{l}$ of $0.5 \%$ trifluoroacetic acid. Tryptic peptides were subjected to mass spectrometry analysis. Peptide mass fingerprints were analyzed and searched against the theoretical spectra of S. citri strains GII3-3X (17) and the unassembled shotgun library sequencing (W. Ma, unpublished data) of another S. citri strain S616. Protein identification was performed using the standard pattern-matching approach.

Antibody evaluation. Polyclonal antibody ScCCPP1 was generated against the protein CAK98563 at Genemed Synthesis, Inc. (San Antonio, TX). The antibody was evaluated using healthy, graft-inoculated, and naturally CSD-infected field citrus, as well as periwinkle plants mechanically inoculated with $S$. citri axenic culture by Western blots or immunoblots with direct tissue print.

For Western blot, phloem-rich tissues (bark and midribs) were excised from stems and leaves of surface-sterilized citrus or periwinkle and ground in liquid nitrogen. The tissue powder was suspended in $2 \times$ Laemmli buffer (35) and the total proteins were separated by $12 \%$ SDS-PAGE. For immunoblots with direct tissue print, 6 to 11 young branches were collected around the canopy of individual citrus trees. Each branch was cut with a sterile razor blade and the fresh cross sections were immediately pressed on a nitrocellulose membrane (Plant Print Diagnostics S.L., Spain). The presence of $S$. citri, as indicated by the presence of the CAK98563 protein, was detected using the ScCCPP1 antibody as the primary antibody and a horseradish peroxidase-conjugated goat-anti-rabbit immunoglobulin G (Santa Cruz Biotechnology Inc., Santa Cruz, CA) as the secondary antibody. The dilution concentrations of primary and secondary antibodies in Western blots and imprint assays were 1:500 and 1:2,000, and 1:3,000 and $1: 30,000$, respectively. The binding of the antibodies with their target proteins were detected by SuperSignal West Pico Chemiluminescent Substrate (Thermo Scientific) following the manufacturer's instructions.

Quantitative qPCR for $S$. citri detection. Total nucleic acid was extracted from citrus and periwinkle using an optimized pro-

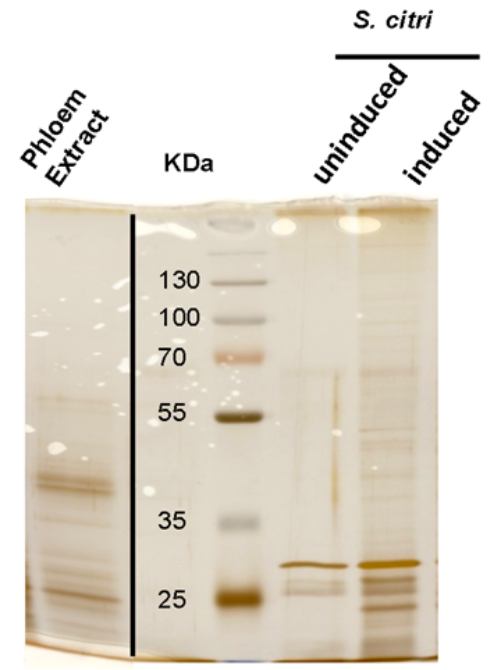

Fig. 1. Protein secretion of Spiroplasma citri was induced by citrus phloem extract. $S$. citri cells cultivated in artificial medium were suspended in $0.3 \mathrm{M}$ sucrose solution and incubated in the presence or absence of phloem extracts. Secreted proteins in the supernatant portion of the cell suspension were precipitated and separated in sodium dodecyl sulfate polyacrylamide gel electrophoresis. The gel was stained with silver nitrate for visualization. cedure for citrus phloem tissues modified from a previously reported protocol (44). The system utilized Cryo-station and Geno Grinder 2010 (SPEX SamplePrep, NJ), the MagMAX Express-96 (Life Technologies, Carlsbad, CA), and the MagMAX-96 Viral RNA Isolation Kit (Life Technologies). Briefly, $250 \mathrm{mg}$ of plant tissue (midveins or midribs) was placed in a 2-ml Eppendorf tube and submerged in liquid $\mathrm{N}_{2}$ for $30 \mathrm{~s}$. Two 5/32-in. stainless-steel grinding balls were added in each tube along with $600 \mu \mathrm{l}$ of guanidine extraction buffer and then placed in the cryo-blocks of Geno Grinder 2010, where the tissue was ground for 20 to $30 \mathrm{~s}$ at $1,750 \mathrm{rpm}$. The crude homogenate was then centrifuged at $4^{\circ} \mathrm{C}$ for $30 \mathrm{~min}$ on a bench-top centrifuge at $14,000 \mathrm{rpm}$. The supernatant was subjected to total nucleic acid extraction, as described by Osman et al (44). Total nucleic acid was suspended in $50 \mu \mathrm{l}$ of elution buffer.

A quantitative PCR (qPCR) assay using a fluorogenic (TaqMan) probe was developed to improve the detection of $S$. citri. Two primers, CCPPscitriJFD-F (5'-ATTGCAGCACCTGC AACTGTAG- $\left.3^{\prime}\right)$ and CCPPscitriJFD-R (5'-TGTTTTTACAA CTCCTTGCACTGC-3'), and a probe, CCPPscitriJFD-P (5'-AC AGCGTTAGAAGCTAAT-3'), were designed to amplify the spiralin gene of S. citri (GenBank accession numbers AF012877, AM285305, AM157770, U13996, U13994, U13995, U13998, FJ755921, U13997, HM641856, HM641861, HM641857, HM641859, HM641854, HM641860, HM641855, and HM641858) using Beacon Designer (Premier Biosoft). The probe was labeled with FAM dye on the $5^{\prime}$ end and with minor groove binder nonfluorescent quencher on the $3^{\prime}$ end (Applied Biosystems).

Each TaqMan qPCR reaction consisted of $300 \mathrm{nM}$ forward primer, $600 \mathrm{nM}$ reverse primer, $200 \mathrm{nM}$ probe, $2 \mu$ l of DNA extract from plant tissue, or $1 \mu$ of $S$. citri cell culture in a total volume of $20 \mu \mathrm{l}$ of $1 \times$ iTaq universal probe supermix (Bio-Rad). The PCR reactions were performed on a CFX96 Real-Time PCR System (Bio-Rad). Control samples in each run included DNA extracted from CSD-infected and healthy plants and $S$. citri culture.

In order to estimate the $S$. citri DNA concentration in unknown samples and determine the detection threshold, a standard curve of TaqMan qPCR was generated following a protocol by Applied Biosystems. For this purpose, a partial spiralin gene was cloned into the pGEMT-Easy vector (Promega Corp.) and serial dilutions of the recombinant plasmid DNA were used to generate the standard curve.

\section{RESULTS}

Identification of secreted proteins from $S$. citri. $S$. citri can be cultivated in artificial media $(36,39)$, which allowed us to experimentally analyze the secreted proteins using a proteomic approach. The cells were induced in $0.3 \mathrm{M}$ sucrose solution because it did not interfere with the subsequent proteomic analysis and also mimicked the major solute composition in the phloem. We further added a crude phloem extract from sweet orange seedlings in order to mimic the environmental condition of the habitat of S. citri. Indeed, in the presence of phloem extract, more secreted proteins were observed from $S$. citri compared with the noninduced cells (Fig. 1), indicating that $S$. citri secreted specific proteins during infection.

According to mass spectrometry results from three independently prepared samples, we identified candidate $S$. citri-secreted proteins with relatively greater abundance, especially in the presence of phloem extracts (Table 1). These proteins were further analyzed for their identity.

Identification of Sec-secreted proteins. Similar to other insect-transmitted bacterial pathogens, S. citri does not have specialized protein delivery systems (48). Therefore, we assumed that most of the secreted proteins are secreted in a Sec-secretion system-dependent manner. Sec-secreted proteins contain a con- 
served N-terminal signal peptide that can be readily predicted using established bioinformatics tools, such as SignalP 4.0 (http://www.cbs.dtu.dk/services/SignalP-4.0/) (46) and SOSUIsignal (http://bp.nuap.nagoya-u.ac.jp/sosui/sosuisignal/) (29). This peptide cannot be detected from the candidate sequences identified from our proteomic analysis because the Sec-secreted proteins are cleaved at a peptidase recognition site following the signal peptide immediately after secretion (51).

To determine potential Sec-dependent secretion of the candidate proteins, we examined their complete sequence for the presence or absence of Sec signal peptide at the $\mathrm{N}$ termini. The corresponding gene sequences encoding the candidate-secreted proteins were extracted from the genome sequences of $S$. citri strains GII3-3X (17) and S616 (W. Ma, unpublished data). The deduced amino acid sequences were analyzed using the program SignalP 4.0. The presence of a putative Sec signal peptide was further confirmed using another program, SOSUIsignal. The sequence analysis confirmed that all six of the S. citri proteins with relatively high abundance in the presence of citrus phloem extract carried an N-terminal Sec signal peptide (Table 1). Furthermore, these six proteins also have the conserved peptidase recognition site in their $\mathrm{N}$-termini following the Sec signal peptide, suggesting a high likelihood that they would be secreted in a Sec-dependent manner.

Detection marker development. To select the candidatesecreted proteins as detection markers, we chose proteins that can fulfill the following criteria: (i) relatively higher abundance and stability indicated by larger number of peptides detected in the mass spectrometry analysis, (ii) unique sequence for spiroplasmas or $S$. citri with no homologous genes in plants or other organisms, (iii) conserved in the S. citri strains (GII3-3X and S616) whose partial sequences are available, and (iv) absence of transmembrane domains. Some Sec-secreted proteins contain transmembrane domains and are anchored to the cell membrane after being secreted from the cell (3). These proteins are not suitable for detection under our working hypothesis. Based on these criteria, we focused on the protein CAK98563 for further development as a CSD detection marker.

To generate antibodies against CAK98563, we cloned the gene excluding the predicted N-terminal Sec signal peptide into an Escherichia coli expression vector pET28a (Novagen). However, the recombinant protein was insoluble when overexpressed in E. coli; therefore, a different strategy was used. We directly generated a polyclonal antibody against two synthesized peptides within the CAK98563 sequence excluding the predicted signal peptide. This antibody, called ScCCPP1, was able to detect CAK98563 from E. coli expressing the recombinant protein or from the cell culture of $S$. citri (Fig. 2A). Importantly, Western blots developed with this antibody confirmed that CAK98563 was induced by the phloem extract and secreted to the medium by $S$. citri growing in liquid culture (Fig. 2A).

In addition to ScCCPP1, we generated a polyclonal antibody against spiralin, one of the most abundant cell-membrane proteins of $S$. citri (25). Similar to ScCCPP1, the anti-spiralin antibody also strongly detected the spiralin proteins from $E$. coli expressing the recombinant protein and from the cell culture of $S$. citri (Fig. 2B). In contrast to CAK98563, spiralin was not induced by the phloem extract, consistent with its function as a major component of the cell membrane. The anti-spiralin antibody, which only detected the $S$. citri cells, was used as a comparison with ScCCPP1, which was hypothesized to detect CSD in the absence of $S$. citri cells.

Evaluation of ScCCPP1 for CSD detection. Direct tissue print immunoblot is an effective, antibody-based detection method for field surveys because of the use of simple experimental equipment and sample preparation (14-16,27). We imprinted young branches and petioles on nitrocellulose membrane and incubated them with either ScCCPP1 or anti-spiralin antibody. ScCCPP1 gave clear positive signals from citrus graft inoculated with both S616 and C189 S. citri strains, whereas the healthy tissues didn't show any signal (Fig. 3A). In addition, no signal was detected with the anti-spiralin antibody for all the samples, including the healthy and the $S$. citri-graft-inoculated trees (Fig. $3 \mathrm{~A})$. The failure of detection by anti-spiralin antibody was likely due to the low titers or the absence of $S$. citri cells in these particular samples. Nonetheless, ScCCPP1 successfully detected CSD-infected trees using the same samples.

We next evaluated ScCCPP1 for CSD detection using both graft-inoculated and naturally infected trees from the field using direct tissue prints. First, we examined healthy samples from three different citrus species-navel orange (Citrus sinensis L. Osb), sour orange $(C$. aurantium L.), and mandarin (C. reticulata Blanco)-and samples graft infected with $S$. citri strains S616, S600, and C189 (Fig. 3B). ScCCPP1 could clearly distinguish uninfected trees from the infected trees, which showed positive signals from multiple stem prints. Furthermore, the detected signals were located in the phloem area of the stems (notice the clear area of the pith in the center of the stem print). This was consistent with the primary localization of $S$. citri as a phloem-

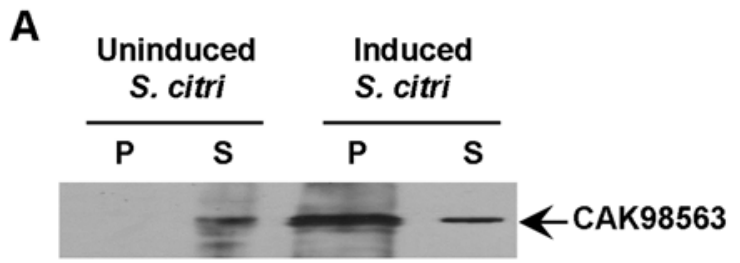

B

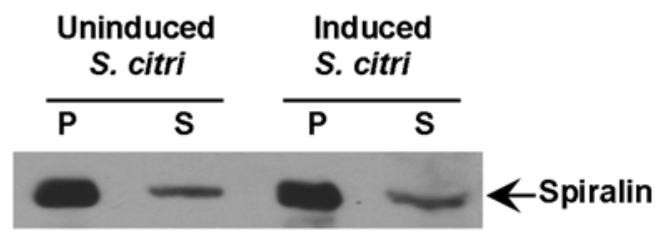

Fig. 2. Antibodies raised against Spiroplasma citri proteins CAK98563 and spiralin could detect the corresponding proteins in $S$. citri cell culture. A, CAK98563 was present in the supernatant (S) portion of the cell suspension and highly induced by the phloem extract. B, Spiralin was mainly present in the cell pellet $(\mathrm{P})$ and its abundance was unchanged in the presence of phloem extract. The relatively small amount of spiralin that was also detected in the supernatant (S) portion was likely due to cell debris from broken cells after centrifugations.

TABLE 1. Candidate-secreted proteins of Spiroplasma citri that were identified by mass spectrometry in three biological replicates

\begin{tabular}{|c|c|c|c|c|c|c|}
\hline \multirow{2}{*}{$\frac{\text { Accession number }}{\text { CAK99824 }}$} & \multirow{2}{*}{$\frac{\text { Location }}{\text { Chromosome }}$} & \multirow{2}{*}{$\frac{\text { Signal peptide prediction }^{\mathrm{a}}}{0.843}$} & \multirow{2}{*}{$\frac{\text { Predicted cleavage site }}{23}$} & \multicolumn{3}{|c|}{ Number of peptide hits in mass spectrometry } \\
\hline & & & & 1 & 12 & 13 \\
\hline CAK99227 & Chromosome & 0.998 & 29 & 5 & 1 & 8 \\
\hline CAK99727 & Chromosome & 0.906 & 30 & 3 & 1 & 1 \\
\hline CAL00019 & Chromosome & 0.75 & 27 & 2 & 3 & 3 \\
\hline CAK98956 & Chromosome & 0.99 & 29 & 3 & 1 & 1 \\
\hline CAK98563 & Chromosome & 0.777 & 23 & 1 & 5 & 5 \\
\hline
\end{tabular}

a Signal peptides were predicted by SignalP 4.0 and then further confirmed by SOSUIsignal. 
A

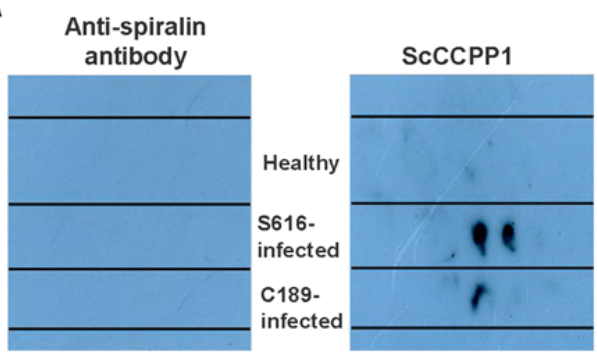

B

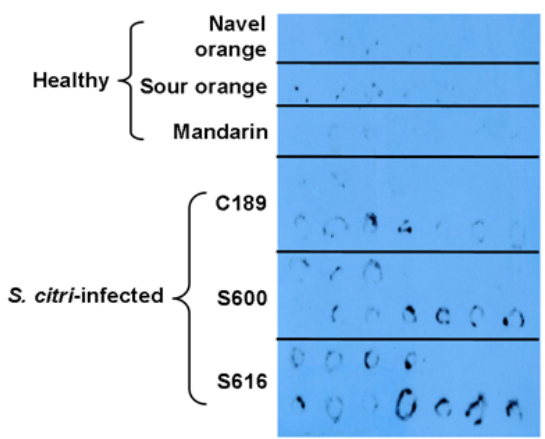

C

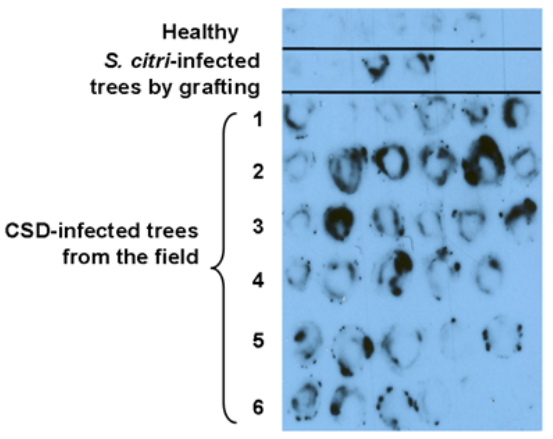

D

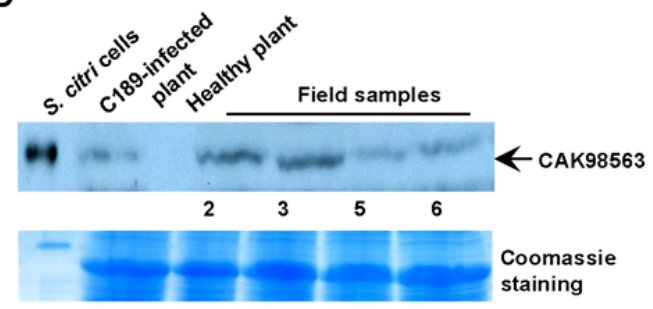

Fig. 3. ScCCPP1 antibody successfully and specifically detects Spiroplasma citri using direct tissue prints of leaf petioles and stems. A, Three stems and two leaf petioles from sweet orange (Citrus sinensis L. Osb.) seedlings graft inoculated with two $S$. citri strains (S616 and C189), respectively were printed on nitrocellulose membranes. The membranes were incubated with antibodies generated against CAK98563 (ScCCPP1) or spiralin. Anti-spiralin antibody failed to give positive signals from the same samples, suggesting that these samples do not contain pathogen cells or low titers. B and C, Stem imprints showing positive signals from the naturally infected citrus stubborn disease (CSD) field sweet orange trees. Up to 11 stems from each of the healthy or $S$. citri graft-inoculated trees (B) or CSD naturally infected field trees (C) were printed on membranes, which were then incubated with the ScCCPP1 antibody. Four of the six field trees were also examined using Western blots (D). Positive signals present exclusively in the regions corresponding to the phloemrich tissues (barks) of a branch, where the bacterium and, presumably, the CAK98563 protein should be located. Also note that not all tested branches exhibited positive signals, indicating the sporadic distribution of the disease. Samples were collected in October 2012 or April 2013. D, Western blots detecting the CAK98563 protein from proteins extracted either from a citrus seedling that was grafting-inoculated with S. citri (lane 2) or from four CSD naturally infected adult trees from the field (lanes 4 to 7). Proteins extracted from $S$. citri cells (lane 1) were used as a positive control. Arrowhead indicates the position of CAK98563 based on its predicted molecular weight. limited pathogen and its secreted proteins. We next examined six adult trees that were known to be naturally infected with CSD from the field using the imprint assay (Fig. 3C). Again, all six naturally infected trees showed positive signals from the phloem area of the stem prints using ScCCPP1.

We further confirmed the detection of CAK98563 in S. citriinfected citrus by Western blots. Total proteins were extracted from the phloem-rich tissues of healthy or infected trees, including a graft-inoculated citrus with S. citri strain C189 and four naturally infected trees (Fig. 3C, numbers 2, 3, 5, and 6) that tested CSD positive using the direct tissue print assay (Fig. 3C). For all the samples from CSD-infected trees, we could detect a specific signal at $\approx 43 \mathrm{kDa}$ in Western blots, which is the expected size of CAK98563 (Fig. 3D). A signal with the same size was also detected in the cell culture of $S$. citri strain C189 but it was absent in the healthy tree, further confirming that CAK98563 was, indeed, present in the CSD-infected trees.

We next compared the ScCCPP1-based imprint method with a newly developed TaqMan qPCR using the same citrus samples, including three graft-inoculated citrus plants and nine field trees. Six of these nine field trees (samples 4 to 9) are known to be naturally infected with CSD (i.e., they have typical CSD infection symptoms and tested positive for CSD at least once previously). Our results showed that all graft-inoculated citrus plants tested positive by both methods, as expected (Table 2). Furthermore, all six naturally infected trees from the field (samples 4 to 9) tested positive in the imprint assay; however, one of these trees tested negative by qPCR, demonstrating that the imprint assay, in this case, has a lower false-negative rate than qPCR. Samples 1 to 3 are adult trees from the field, and it was not known whether or not they were CSD infected. Sample 1 tested positive in both assays, suggesting that this tree was also naturally infected with CSD. Sample 3 tested negative in both assays; therefore, it is likely uninfected. Sample 2 tested negative by qPCR but positive by the imprint assay. We will monitor the potential disease symptoms and retest this tree at a later time to determine whether it is, indeed, CSD infected.

Evaluation of ScCCPP1 to detect $S$. citri infection in periwinkle. In order to confirm the detection of $S$. citri by ScCCPP1 in periwinkle, mechanical inoculation of periwinkle with $S$. citri strain C189 was monitored for the presence of CAK98563 in a time course experiment. Samples were collected after biojector inoculation at 8 and 20 dpi from newly emerged tissues, away from the inoculation sites, and DNA was extracted and tested by qPCR. Of the three plants that were inoculated, two (namely, E1 and E2) tested positive by $\mathrm{qPCR}$ at $8 \mathrm{dpi}$, indicating that the pathogen was established in the plants (Fig. 4A). Furthermore, E1 still tested positive by qPCR at $20 \mathrm{dpi}$, suggesting that this plant was successfully infected by $S$. citri. On the other hand, plant E3

TABLE 2. Comparison of quantitative polymerase chain reaction (qPCR) and direct tissue print results for citrus field samples ${ }^{\mathrm{a}}$

\begin{tabular}{lcc}
\hline Samples & qPCR & Imprint \\
\hline Negative control & - & - \\
Positive control A (C189) & + & + \\
Positive control B (S600) & + & + \\
Positive control C (S616) & + & + \\
Field sample 1 & + & + \\
Field sample 2 & - & + \\
Field sample 3 & - & - \\
Field sample 4 & + & + \\
Field sample 5 & - & + \\
Field sample 6 & + & + \\
Field sample 7 & + & + \\
Field sample 8 & + & + \\
Field sample 9 & + & +
\end{tabular}

${ }^{a}$ Citrus seedlings graft inoculated with three Spiroplasma citri strains were used as positive controls. 
tested negative in both time points. Importantly, using ScCCPP1, both E1 and E2 but not E3 tested positive at 8 weeks postinoculation (Fig. 4B). Furthermore, E1 seemed to show a stronger signal than E2, consistent with the more persistent infection of S. citri developed in E1 (Fig. 4A).

\section{DISCUSSION}

The citrus industry is facing major threats from severe invasive diseases caused by bacterial pathogens such as HLB and citrus variegated chlorosis, as well as emerging endemic bacterial diseases such as CSD (52). These diseases are especially difficult to manage because the causal pathogens are transmitted by prolific insect vectors and reside in the plant vascular systems. Because there is no cure for these diseases once trees are infected, early detection becomes extremely important for disease management. However, detection of these pathogens is further complicated due to the uneven distribution or low titers in infected trees coupled with large seasonal variation. The sporadic distribution of the pathogens is specifically challenging for diagnosis of trees. In fact, pathogen cells frequently cannot be detected even in symptomatic branches or leaves. Moreover, nucleic-acid-based assays require complex sample preparations, which make them costly and time consuming, especially when multiple samples have to be collected and tested from one tree to compensate for erratic pathogen distribution and titer $(4,6,45,55)$.

In this article, we report the novel concept of using pathogensecreted proteins as detection targets and the development of a novel antibody-based diagnostic method that can detect CSD using a preparation-free direct tissue print assay. CAK98563 was found to be a protein secreted by $S$. citri cells which is unique to $S$. citri yet present in the four different $S$. citri strains (C189, S600, S616, and GII3-3X) tested. S. citri secreted CAK98563

\section{A}

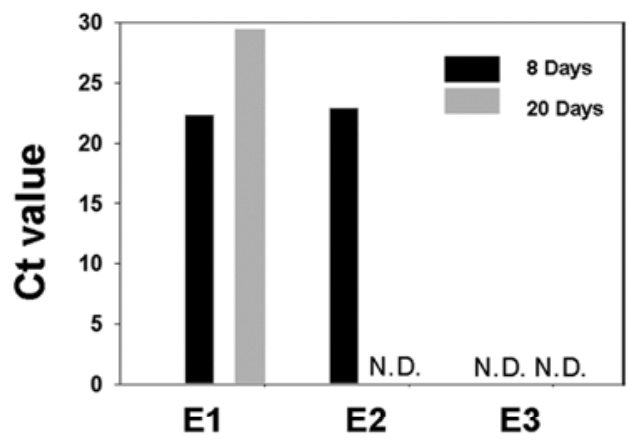

B
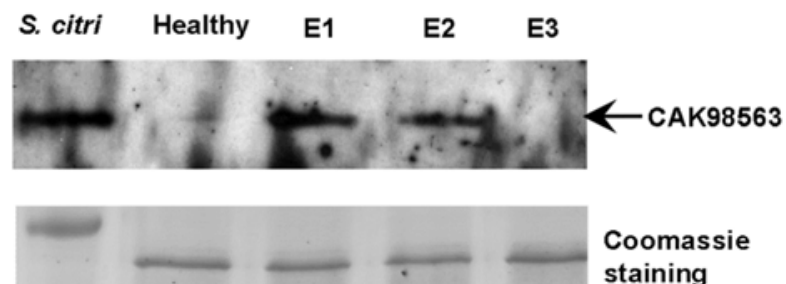

Fig. 4. ScCCPP1 detected Spiroplasma citri infection in periwinkle plants that were mechanically inoculated with $S$. citri strain C189. Periwinkle seedlings were inoculated with $S$. citri cell suspensions on the stem. Data include three replicates (E1, E2, and E3). A, Newly emergent leaf tissues were collected 8 and 20 days postinoculation for quantitative polymerase chain reaction analysis using primers amplifying the spiralin gene of $S$. citri. $\mathrm{Ct}=$ cycle threshold. B, Western blots using ScCCPP1 antibody to detect the CAK98563 proteins were performed 8 weeks postinoculation using tissues away from the inoculation sites from the same three replicates as in A. abundantly, especially in the presence of citrus phloem extract; hence, an antibody was subsequently produced against CAK98563. By detecting this secreted protein as a marker, CSD-infected trees were successfully diagnosed in a highly reliable and specific manner in direct tissue prints on nitrocellulose membrane.

The imprint assay developed using ScCCPP1 antibody generated against CAK98563 is simple and essentially samplepreparation-free. Antibody-based diagnosis is widely used due to its high specificity, robustness, low cost, and adaptability for large-scale field surveys with minimum laboratory equipment $(2,16)$. Therefore, we believe that the use of ScCCPP1 is the first documentation of serological diagnosis for CSD that is independent of the presence of the $S$. citri in the tested sample. This should reduce the sample number per tree to be tested and may be suitable for large-scale field surveys. For such application, however, additional validation and specificity confirmation of the method is required. For example, ScCCPP1 testing of large numbers of field samples from several additional citrus species at different tree ages and developmental stages, co-infected with other bacterial and viral pathogens of citrus, at different times of the year and in different geographic locations will generate critical data for the suitability of the method for field deployment.

Visual inspections for symptom identification are critical elements of the currently available HLB management systems $(4,6)$. However, in California or other areas where CSD is endemic, the introduction of HLB will take place in addition to $S$. citri infection. Given symptom similarities of CSD and HLB, the introduction of HLB may be readily confused or ignored as CSD if the only means of large-scale field surveys is visual inspection $(11,45)$. In addition, visual misidentification of CDS as HLB may trigger unnecessary regulatory actions or management practices. A large-scale field-applicable serological method such as the ScCCPP1 will be of great importance for the differentiation of CSD and HLB infected trees.

Compared with PCR-based assays, ScCCPP1-based direct tissue print detection can overcome uneven distribution or low titers of $S$. citri in the infected plants, thereby reducing falsenegative diagnosis $(55,56)$. This challenge was clearly demonstrated from this study, where qPCR results were inconsistent with imprint data in detecting CSD-infected field trees (Table 2). From the direct tissue print assays using ScCCPP1, we observed positive signals from the phloem-rich tissues without the actual presence of pathogen cells. These data suggest that the detection marker was dispersed in the phloem, potentially moving along with the transportation flow. Therefore, this study set up a novel concept of using secreted proteins as markers to detect diseases caused by pathogens that reside in plant vascular tissues. Systemic movement of bacterial-secreted proteins has been reported in phytoplasmas $(3,31,41)$, which are also insect-transmitted and phloem-colonizing plant pathogens. Therefore, use of pathogensecreted proteins as detection markets can likely be adapted for other ecologically similar pathosystems, such as the devastating citrus HLB.

\section{ACKNOWLEDGMENTS}

This work was supported by a grant from the Citrus Research Board (5300-139) to W. Ma and G. Vidalakis. We thank UC Riverside CCPP personnel J. Wang, F. Osman, and C. Nguyen for technical assistance; T. Kahn for giving us access to the Citrus Variety Collection; and W. Dawson at the University of Florida for providing the biojector gun.

\section{LITERATURE CITED}

1. Abramovitch, R. B., Anderson, J. C., and Martin, G. B. 2006. Bacterial elicitation and evasion of plant innate immunity. Nat. Rev. Mol. Cell Biol. 7:601-611.

2. Ahangaran, A., Mohammadi, G. M., Habibi, M. K., Shahraeen, N., and Khezri, S. 2006. Rapid diagnosis of Soybean mosaic virus $N$ soybean by 
tissue-print immunoassay and DIBA in comparison to other serological methods. Commun. Agric. Appl. Biol. Sci. 71:1207-1212.

3. Bai, X. D., Correa, V. R., Toruno, T. Y., Ammar, E. D., Kamoun, S., and Hogenhout, S. A. 2009. AY-WB phytoplasma secretes a protein that targets plant cell nuclei. Mol. Plant-Microbe Interact. 22:18-30.

4. Belasque, J., Jr., Bassanezi R., Yamamoto P., Ayres A., Tachibana A., Violante A., Tank, A., Jr., Di Giorgi, F., Tersi, F., and Menezes, G. 2010. Lessons from huanglongbing management in São Paulo State, Brazil. J. Plant Pathol. 92:285-302.

5. Bové, J. M. 1995. Virus and Virus-Like Diseases of Citrus in the Near East Region. FAO U.S.A. Publications Division, Rome.

6. Bové, J. M. 2006. Huanglongbing: A destructive, newly emerging, century-old disease of citrus. J. Plant Pathol. 88:7-37.

7. Bové, J. M., and Garnier, M. 2000. Stubborn. Page 48-50 in: Compendium of Citrus Diseases. L. W. Timmer, S. M. Garnsey, and J. H. Graham, eds. American Phytopathological Society Press, St. Paul, MN.

8. Bové, J. M., and Saglio, P. 1974. Stubborn and greening: a review, 19691972. Pages 1-11 in: Proc. 6th Conf. Int. Organ. Citrus Virol. L. G. Weathers and M. Cohen, eds. University of California, Riverside.

9. Bowyer, J. E. C. 1974. Antibiotic sensitivity in vitro of the mycoplasmalike organism associated with citrus stubborn disease. Phytopathology 64:346-349.

10. Brown, L. G. 1992. Stubborn disease of citrus. Plant Pathol. Circ. Jan.Feb. 351 Fla. Dep. Agric. Consumer Serv. Div. Plant Ind., Gainesville, FL.

11. Calavan, E. C. 1968. A review of stubborn and greening diseases of citrus. Pages 105-117 in: Proc. 4th Conf. Int. Organ. Citrus Virol. J. F. L. Childs, ed. University of California, Riverside.

12. Calavan E. C. 1969. Investigations of stubborn disease in California: indexing, effects on growth and production, and evidence for virus strains. Pages 1403-1412 in: Proc. First Int. Citrus Symp. H. D. Chapman, ed. University of California, Riverside.

13. Calavan, E. C., and Carpenter, J. B. 1965. Stubborn disease of citrus tree retards and growth, impairs quality and decrease yields. Calif. Citrogr. 50(3):86-87, 96, 98-99.

14. Cambra, M., Gorris, M., Olmos, A., Martínez, M., Román, M., Bertolini, E., López, A., and Carbonell, E. 2002. European diagnostic protocols (DIAGPRO) for Citrus tristeza virus in adult trees. Pages 69-77 in: Proc. 15th Conf. Int. Organ. Citrus Virol. J. V. Da Graça, R. F. Lee, and R. K. Yokomi, eds. University of California, Riverside.

15. Cambra, M., Gorris, M., Roman, M., Terrada, E., Garnsey, S., Camarasa, E., Olmos, A., Colomer, M., da Graça, J., and Lee, R. 2000. Routine detection of Citrus tristeza virus by direct immunoprinting-ELISA method using specific monoclonal and recombinant antibodies. Pages 34-41 in: Proc. 14th Conf. Int. Organ. Citrus Virol. J. V. Da Graça, R. F. Lee, and R. K. Yokomi, eds. University of California, Riverside.

16. Cambra, M., Olmos, A., Gorris, M. T., Duran, N., Roman, M. P., Camarasa, E., and Dasi, M. A. 1997. Sensitive detection of plant pathogens by using immobilized targets in tissue imprinted membranes. In: Diagnosis and Identification of Plant Pathogens. H. W. Dehne, G. Adam, M. Diekmann, J. Frahm, A. Mauler-Machnik, and P. Halteren, eds. Kluwer Academic Publishers, London.

17. Carle, P., Saillard, C., Carrere, N., Carrere, S., Duret, S., Eveillard, S., Gaurivaud, P., Gourgues, G., Gouzy, J., Salar, P., Verdin, E., Breton, M., Blanchard, A., Laigret, F., Bové, J. M., Renaudin, J., and Foissac, X. 2010. Partial chromosome sequence of Spiroplasma citri reveals extensive viral invasion and important gene decay. Appl. Environ. Microbiol. 76:3420-3426.

18. Clark, M. F., Flegg, C. L., Bar-Joseph, M., and Rottem, S. 1978. The detection of Spiroplasma citri by enzyme-linked immunosorbent assay (ELISA). J. Phytopathol. 92:332-337.

19. Davis, R. 1981. Antibiotic sensitivities in vitro of diverse spiroplasma strains associated with plants and insects. Appl. Environ. Microbiol. 41:329-333.

20. Duan, Y. P., Zhou, L. J., Hall, D. G., Li, W. B., Doddapaneni, H., Lin, H., Liu, L., Vahling, C. M., Gabriel, D. W., Williams, K. P., Dickerman, A., Sun, Y. J., and Gottwald, T. 2009. Complete genome sequence of citrus huanglongbing bacterium, 'Candidatus Liberibacter asiaticus' obtained through metagenomics. Mol. Plant-Microbe Interact. 22:1011-1020.

21. EPPO/CABI (European and Mediterranean Plant Protection Organization). 1997. Spiroplasma citri. In: Quarantine Pests for Europe: Data Sheets on Quarantine Pests for the European Union and for the European and Mediterranean Plant Protection Organization, 2nd ed. I. M. Smith, ed. $\mathrm{CAB}$ International (in association with the European and Mediterranean Plant Protection Organization), Wallingford, UK.

22. Espinosa, A., and Alfano, J. R. 2004. Disabling surveillance: Bacterial type III secretion system effectors that suppress innate immunity. Cell. Microbiol. 6:1027-1040.

23. Fletcher, J. 1987. Filter paper dot-immunobinding assay for detection of Spiroplasma citri. Appl. Environ. Microbiol. 53:183-184.
24. Fletcher, J., Schultz, G. A., Davis, R. E., Eastman, C. E., and Goodman, R. M. 1981. Brittle root disease of horseradish-evidence for an etiological role of Spiroplasma citri. Phytopathology 71:1073-1080.

25. Foissac, X., Saillard, C., Gandar, J., Zreik, L., and Bové, J. M. 1996. Spiralin polymorphism in strains of Spiroplasma citri is not due to differences in posttranslational palmitoylation. J. Bacteriol. 178:29342940.

26. Garnier, M., Latrille, J., and Bové, J. M. 1976. Spiroplasma citri and the organism associated with likubin: Comparison of their envelope systems. Pages 13-17 in: Proc. 7th Conf. Int. Organ. Citrus Virol. E. C. Calavan, ed. University of California, Riverside.

27. Garnsey, S., Permar, T., Cambra, M., and Henderson, C. 1993. Direct tissue blot immunoassay (DTBIA) for detection of citrus tristeza virus (CTV). Pages 39-50 in: Proc. 12th Conf. Int. Organ. Citrus Virol. P. Moreno, J. V. da Graça and L. W. Timmer, eds. University of California, Riverside.

28. Gasparich, G. E. 2010. Spiroplasmas and phytoplasmas: Microbes associated with plant hosts. Biologicals 38:193-203.

29. Gomi, M., Sonoyama, M., and Mitaku, S. 2004. High performance system for signal peptide prediction: SOSUIsignal. Chem.-Biol. Inf. J. 4:142-147.

30. Gumpf, D. J., and Calavan, E. C. 1981. Stubborn disease of citrus. Pages 97-134 in: Mycoplasma Diseases of Trees and Shrubs. K. Maramorosch and S. P. Raychaudhuri, eds. Academic Press, New York.

31. Hoshi, A., Oshima, K., Kakizawa, S., Ishii, Y., Ozeki, J., Hashimoto, M., Komatsu, K., Kagiwada, S., Yamaji, Y., and Namba, S. 2009. A unique virulence factor for proliferation and dwarfism in plants identified from a phytopathogenic bacterium. Proc. Natl. Acad. Sci. USA 106:6416-6421.

32. Igwegbe, E. C. K. 1973. Effect of tetracycline antibiotics on symptom development of stubborn disease and infectious variegation of citrus seedlings. Phytopathology 63:1044-1048.

33. Kwon, M.-O., Wayadande, A. C., and Fletcher, J. 1999. Spiroplasma citri movement into the intestines and salivary glands of its leafhopper vector, Circulifer tenellus. Phytopathology 89:1144-1151.

34. Kyriakou, A., Eliades, G., Loannou, N., and Kapari-Isaia, T. 1996. Effect of stubborn disease on growth, yield and fruit quality of frost Washington Navel and frost Valencia oranges in Cyprus. J. Hortic. Sci. 71:461-467.

35. Laemmli, U. K. 1970. Cleavage of structural proteins during the assembly of the head of bacteriophage T4. Nature 227:680-685.

36. Lee, I., and Davis, R. 1984. New media for rapid growth of Spiroplasma citri and corn stunt Spiroplasma. Phytopathology 74:84-89.

37. Lee, I. M., Bottner, K. D., Munyaneza, J. E., Davis, R. E., Crosslin, J. M., du Toit, L. J., and Crosby, T. 2006. Carrot purple leaf: A new spiroplasmal disease associated with carrots in Washington state. Plant Dis. 90:989993.

38. Liao, C., Chen, T. A. 1981. In vitro susceptibility and resistance of two spiroplasmas to antibiotics. Phytopathology 71:442-445.

39. Liao, C. H., and Chen, T. A. 1977. Culture of corn stunt spiroplasma in a simple medium. Phytopathology 67:802-807.

40. Lin, H., Lou, B. H., Glynn, J. M., Doddapaneni, H., Civerolo, E. L., Chen, C. W., Duan, Y. P., Zhou, L. J., and Vahling, C. M. 2011. The complete genome sequence of 'Candidatus Liberibacter solanacearum', the bacterium associated with potato Zebra Chip disease. PLoS One 6:e19135.

41. MacLean, A. M., Sugio, A., Makarova, O. V., Findlay, K. C., Grieve, V. M., Toth, R., Nicolaisen, M., and Hogenhout, S. A. 2011. Phytoplasma effector SAP54 induces indeterminate leaf-like flower development in Arabidopsis plants. Plant Physiol. 157:831-841

42. Mello, A., Yokomi, R., Payton, M., and Fletcher, J. 2010. Effect of citrus stubborn disease on navel orange production in a commercial orchard in California. J. Plant Pathol. 92:429-438.

43. Mello, A. F. S., Yokomi, R. K., Melcher, U., Chen, J. C., Wayadande, A C., and Fletcher, J. 2008. Genetic diversity of Spiroplasma citri strains from different regions, hosts, and isolation dates. Phytopathology 98:960968.

44. Osman, F., Olineka, T., Hodzic, E., Golino, D., and Rowhani, A. 2012. Comparative procedures for sample processing and quantitative PCR detection of grapevine viruses. J. Virol. Methods 179:303-310.

45. Polek, M.. Vidalakis, G., and Godfrey, K. 2007. Citrus Bacterial Canker Disease and Huanglongbing (Citrus Greening). UC ANR Publication. Oakland, CA.

46. Petersen, T. N., Brunak, S., von Heijne, G., and Nielsen, H. 2011. SignalP 4.0: Discriminating signal peptides from transmembrane regions. Nat. Methods 8:785-786.

47. Rangel, B., Krueger, R., and Lee, R. 2005. Current research on Spiroplasma citri in California. Pages 439-441 in: Proc. 16th Conf. Int. Organ. Citrus Virol. M. E. Hilf, N. Duran-Vila, and M. A. Rocha-Peña, eds. University of California, Riverside.

48. Saillard, C., Carle, P., Duret-Nurbel, S., Henri, R., Killiny, N., Carrere, S., Gouzy, J., Bové, J. M., Renaudin, J., and Foissac, X. 2008. The abundant extrachromosomal DNA content of the Spiroplasma citri GII3-3X genome. BMC Genomics 9:195 
49. Saillard, C., Garcia-Jurado, O., Bové, J., Vignault, J., Moutous, G., Fos, A., Bonfils, J., Nhami, A., Vogel, R., and Viennot-Bourgin, G. 1980. Application of ELISA to the detection of Spiroplasma citri in plants and insects. Pages 145-152 in: Proc. 8th Conf. Int. Organ. Citrus Virol. E. C. Calavan, S. M. Garnsey, and L. W. Timmer, eds. University of California, Riverside.

50. Song, J., Braun, G., Bevis, E., and Doncaster, K. 2006. A simple protocol for protein extraction of recalcitrant fruit tissues suitable for 2-DE and MS analysis. Electrophoresis 27:3144-3151.

51. Stathopoulos, C., Hendrixson, D. R., Thanassi, D. G., Hultgren, S. J., St Geme, J. W., III, and Curtiss, R., III. 2000. Secretion of virulence determinants by the general secretory pathway in Gram-negative pathogens: An evolving story. Microbes Infect. 2:1061-1072.

52. Strategic Planning for the Florida Citrus Industry: Addressing Citrus Greening. 2010. The National Academies Press, Washington, DC.
53. Sugio, A., Kingdom, H. N., MacLean, A. M., Grieve, V. M., and Hogenhout, S. A. 2011. Phytoplasma protein effector SAP11 enhances insect vector reproduction by manipulating plant development and defense hormone biosynthesis. Proc. Natl. Acad. Sci. USA 108:E1254E1263.

54. Wallace, J. M. 1978. Virus and virus like diseases. In: The Citrus Industry, Vol. 4. W. Reuther, E. C. Calavan, and G. E. Carman, eds. University of California, Division of Agricultural Sciences, Richmond.

55. Yokomi, R. K., Mello, A. F. S., Fletcher, J., and Saponari, M. 2010. Estimation of citrus stubborn incidence in citrus groves by real-time PCR. Pages 131-141 in: Proc. 17th Conf. Int. Organ. Citrus Virol. University of California, Riverside.

56. Yokomi, R. K., Mello, A. F. S., Saponari, M., and Fletcher, J. 2008. Polymerase chain reaction-based detection of Spiroplasma citri associated with citrus stubborn disease. Plant Dis. 92:253-260. 